science and scientific men a kind of wickedness not shared by the humanities and by those engaged in their study". This kind of tilting at science is familiar enough. It springs from a failure to recognize that science is neither good nor evil; it is man who uses science for his good or evil ends. No one who reads these two addresses can avoid the conclusion that science can be, and is being, used for wholly beneficent ends and that countless men and women all over the world, as well as countless technicians who assist them, are devoting their lives to the betterment of the lot of humanity and sometimes are losing their lives in this service.

Sir Edward Mellanby's address deals with the organization and duties of the Medical Research Council and with organized medical research on blood transfusion, nutrition, problems of drug supply, the emergency public health laboratory service and the application of medical research to the needs of the fighting services. He inevitably makes contact, through his references to the sulphonamide drugs and to penicillin and other antiseptics, with Sir Henry Dale's more detailed history of these and other pharmacological discoveries. Sir Henry points to future fields of work and to still more remarkable benefits to come. We live, it is clear, in one of the greatest hours of medical history. The depreciators of science should consider, after reading these two records of lives saved, suffering reduced and hope for a better future securely established, whether science, properly used, is not one of the greatest of the humanities. Has any other human activity brought, in so short a time as the interval between the War of 1914-18 and that of to-day, so much effective and practical aid to the sick, the distressed and the broken in mind and limb?

\section{Glaxo Laboratories' Products}

THE flavines or amino-acridines have long been known as antiseptics that are particularly effective in the presence of serum, which diminishes the activity of most other antiseptics. Acriflavine, which is the one generally used, has also trypanocidal powers, hence the name trypoflavine. Glaxo Laboratories, Ltd., of Greenford, Middlesex, have just introduced $2: 7$ diamino-acridine hydrochloride and 5 : amino-acridine hydrochloride. The former is stated to have the least toxicity of all the flavines, and, while not interfering with healing, to be rapidly bactericidal. It is effective against certain Gram-negative organisms not affected by other acridines in similar concentrations. The latter is a non-irritant antiseptic with an antibacterial activity similar to that of other flavines and has the advantage of not staining the skin.

Other products which this firm is introducing are nicotinamide, which possesses a similar therapeutic value to nicotinic acid without producing the uncomfortable flushing and other skin reactions so common with the acid, and Suspended T.A.B. Vaccine.(synthetic culture medium). It is stated that by using a synthetic culture medium free from the protein and other substances contained in the usual bacteriological broth and nutrient agar, reaction from the use of such substances is avoided. The full antigenic properties of the organisms are retained, while the absence of protein from the culture medium restricts the reaction to that produced by the bacteria themselves. It is claimed that the reactions from this T.A.B. vaccine are few, principally of local pain and stiffness at the site of the injection, while the antigenic response is extremely satisfactory.

\section{Colonial Fisheries Advisory Committee}

THE Secretary of State for the Colonies has appointed a Colonial Fisheries Advisory Committee to advise him on problems concerning fisheries (marine and freshwater) in the Colonial Empire, in association with his fisheries adviser. The committee is constituted as follows : The Duke of Devonshire, Parliamentary Under-Secretary of State for the Colonies (chairman); Mr. G. L. M. Clauson, Colonial Office (vice-chairman); Dr. S. Kemp, director of the Marine Biological Association of the United Kingdom; Dr. E. B. Worthington, director of the Freshwater Biological Association of the British Empire; Dr. E. S. Russell, fisheries adviser to the Secretary of State for the Colonies; Dr. G. A. Reay, director of the Torry Research Institute (Department of Scientific and Industrial Research), Aberdeen ; Dr. B. S. Platt, in charge of investigations into nutrition in the Colonial Empire under the Medical Research Council; Mr. J. R. Norman, deputy keeper, Department of Zoology, British Museum (Natural History); Dr. C. F. A. Pantin, reader in invertebrate zoology, University of Cambridge; Mr. R. S. Wimpenny, naturalist, Ministry of Agriculture and Fisheries; Mr. J. Thomson, chief inspector of fisheries, Ministry of Agriculture and Fisheries ; Mr. Morley Neale, member of the firm of Messrs. Neale and West, steam trawler owners, Cardiff ; Mr. C. N. Hooper, clerk of the Fishmongers, Company; Mr. R. H. Burt, Colonial Office (secretary).

\section{Telecommunication}

IN his inaugural address to the Institution of Electrical Engineers on October 7, Sir A. Stanley Angwin, president of the Institution, gave a survey of the possibilities of development of telecommunications in the international field, dealing particularly with the subject of international control and regulation and its repercussions on post-war developments in Great Britain. In dealing with international control and standardization, Sir Stanley referred to the various administrative international regulations which had come into being and to the three technical com mittees which studied technical questions relating to the methods of working communication channels. Reference was made to other international organizations dealing with the application of communication for a particular purpose.

The necessity for emphasis being given to the adoption of a technical basis in determining international frequency allocations leads to consideration of the three consultative technical committees referred to in the address, and the three divisions of the communications with which they deal, namely, telephony, telegraphy and radio communication. Sir Stanley dealt with the provisions to implement these services on an international basis. Reference was made to the possible developments in connexion with television, but how far these will be divided between radio and line transmission has yet to be determined. How far the employment of micro-waves for radio transmission or the new mechanism of electrical transmission by wave guides will meet the needs of television is one of the intriguing problems of the future.

\section{New 50-Kilowatt C.B.S. International Broadcasters}

AMoNG the foremost short-wave radio broadcast stations in the United States are the C.B.S. International Broadcasters located on Long Island, New York, which transmit around the clock in twenty-three 